\title{
IMPLEMENTASI PERATURAN DAERAH NOMOR 23 TAHUN 20 I 4 TENTANG RETRIBUSI IZIN TEMPAT PENJUALAN MINUMAN BERALKOHOL KOTA PALANGKA RAYA
}

\section{Implementation of regional Regulation No. 23 of 20 I4 concerning retribution permit of alcoholic beverage sales of Palangka Raya City}

Fitriani $^{1}$

Wahyu Rizanu Arifandi ${ }^{2}$

Universitas Muhammadiyah Palangkaraya, Palangka Raya, Central Kalimantan, Indonesia

email:

fitrianimap86@gmail.com

wahyurizanuarifandy@gmail.com

\section{Kata Kunci:}

Implementasi

Retribusi

Izin

\section{Keywords:}

Implementation

Retribution

Permit

\section{Accepted}

Februari 2020

Published

April 2020

\begin{abstract}
Abstrak
Penelitian ini bertujuan untuk mengetahui bagaimana Dinas Perindustrian dan Perdagangan Kota Palangka Raya dalam melaksanakan Peraturan Daerah Nomor 23 Tahun 2014 kepada Penjual Minuman Beralkohol Kota Palangka Raya. Metode yang digunakan adalah kualitatif. Peneliti ingin mendeskripsikan Pelaksanaan Peraturan Daerah Nomor 23 Tahun 2014 dari Dinas Perindustrian dan Perdagangan Kota Palangka Raya kepada Penjual Minuman Beralkohol. Penulis menggunakan 4 (empat) indikator implementasi kebijakan yaitu Informasi, Isi Kebijakan, Dukungan Masyarakat dan Pembagian Potensi. Sumber data terdiri dari data primer yakni hasi wawancara dengan Dinas Perindustrian dan Perdagangan, Penjual Minuman Beralkohol dan masyarakat Kota Palangka Raya, sedangkan sumber data sekunder berupa dokumen resmi Peraturan Daerah Nomor 23 Tahun 2014.

Hasil penelitian mengenai Implementasi Peraturan Daerah Nomor 23 Tahun 2014 masih belum maksimal karena sulitnya beberapa Penjual Minuman Beralkohol untuk hadir tepat waktu dalam menghadiri kegiatan sosialisasi dan masih sulitnya para Penjual Minuman Beralkohol dalam meminta kartu identitas kepada para pembeli remaja. Untuk itu peneliti menyarankan I) memberikan teguran bagi para Penjual Minuman Beralkohol yang terlambat dalam mengikuti kegiatan Sosialisasi dan 2) mempertegas lagi dalam pemberian informasi mengenai Peraturan tentang larangan menjual minuman beralkohol kepada pelajar atau berusia dibawah 17 tahun.
\end{abstract}

\begin{abstract}
This study aims to determine how the Department of Industry and Trade of Palangkarayo City in implementing Regional Regulation No. 23 of 2014 to the Palangkaraya Alcoholic Beverage Seller. The method used is qualitative. The researcher wants to describe the Implementation of Regional Regulation No. 23 of 2014 from the Department of Industry and Trade of Palangka Raya City to the Seller of Alcoholic Beverages. The author uses 4 (four) indicators of policy implementation namely Information, Policy Content, Community Support and Potential Distribution. The data source consists of primary data, namely the results of interviews with Dinas Perindustrian dan Perdagangan, Alcoholic Beverage Sellers and the people of Palangka Raya City, while secondary data sources are in the form of official Regional Regulation Number 23 of 2014.

the results of research on the Implementation of Regional Regulation No. 23 of 2014 are still not optimal due to the difficulty of some Alcoholic Beverage Sellers to be present on time to attend socialization activities and the difficulty of Alcoholic Beverage Sellers in requesting identity cards to teenage buyers. For this reason, the researcher recommends I) giving a warning to the Alcoholic Beverage Sellers who are late in participating in the Socialization activities and 2) reaffirming the provision of information regarding the Regulations on the prohibition of selling alcoholic drinks to students or under 17 years of age.
\end{abstract}




\section{PENDAHULUAN}

Minuman beralkohol di Indonesia yaitu merujuk kepada minuman beralkohol dan industrinya, serta kebijakan hukum mengenai minuman beralkohol di negara Indonesia. Keberadaan minuman beralkohol di Indonesia tidak lepas dari sejarah panjang. Minuman itu kerap disajikan untuk acara adat istiadat maupun upacara keagamaan. Mayoritas penduduk Indonesia adalah orang Muslim, namun Indonesia juga adalah negara yang memiliki keberagaman agama. Kondisi sosial dan demografik tersebut yang mendorong kelompok penekan Islamis terus mendesak pemerintah agar membatasi perdagangan dan konsumsi minuman beralkohol. Sementara pemerintah secara saksama mempertimbangkan hak kaum non-Muslim dan orang dewasa yang bersepakat untuk mengkonsumsi alkohol, seraya mempertimbangkan dampak pelarangan atas minuman beralkohol terhadap ekonomi dan pariwisata di Indonesia.

Penjualan minuman beralkohol di Kalimantan Tengah pada saat ini sudah cukup luas karena hampir di setiap daerah di wilayah Kalimantan Tengah terdapat toko-toko kecil hingga toko besar yang menjual minuman beralkohol. Jenis-jenis yang diperjualbelikanpun berbagai macam mulai minuman beralkohol buatan pabrik, minuman beralkohol yang kerap disebut dengan minuman polos, dan minuman beralkohol tradisional. Penjualan minuman tersebut seakan tidak akan pernah putus karena penikmat minuman beralkohol yang jumlahnya tidak sedikit sehingga menyebabkan permintaan pembelian minuman beralkohol terus terjadi guna memenuhi permintaan konsumen. Sebenarnya keberadaan minuman beralkohol kerap menuai problema di berbagai daerah karena pemikiran dari kebanyakan orang bahwa minuman tersebut hanya mengakibatkan banyak mudharat atau akibat buruk bagi peminumnya dan bagi warga sekitar, namun faktanya minuman beralkohol merupakan salah satu penyumbang pendapatan daerah yang menyumbangkan cukup banyak rupiah bagi Pemerintah Daerah.

Salah satu penyumbang Pendapatan Asli Daerah (PAD) yang cukup tinggi dari hasil penarikan retribusi Minuman Beralkohol di Kalimantan Tengah adalah Kota Palangka Raya. Hal ini terjadi karena di wilayah Kota Palangka Raya telah banyak tempat yang menyediakan berbagai macam variasi Minuman Beralkohol mulai dari yang berkadar rendah sampai yang berkadar tinggi. Penarikan Retribusi ini didapatkan dari sejumlah usaha Minuman Beralkohol, seperti pada karaoke, lokalisasi, toko, restaurant, cafe dan hotel.

Walaupun dengan penjualan Minuman Beralkohol tersebut dapat meningkatkan pendapatan daerah namun beberapa dari masyarakat mengaku cukup resah dengan banyaknya penjualan minuman beralkohol dengan berbagai merk di Kota Palangka Raya. Penyebab keresahan dari masyarakat ini diantaranya karena banyak kasus seperti tawuran, pemerkosaan, kecelakaan lalu lintas yang diakibatkan karena konsumsi Minuman Beralkohol secara berlebihan.

Untuk menghindari dampak negatif dari penjualan minuman berarkohol, Pemerintah juga telah menetapkan tempat-tempat yang dilarang untuk memperjualbelikan minuman beralkohol dan larangan menjual minuman beralkohol kepada pelajar atau berusia dibawah 17 tahun. Peraturan tersebut dituangkan pada pasal 28 (I) dan (2) Peraturan Daerah Kota Palangka Raya nomor 23 Tahun 2014.

Dalam hal peredaran dan penjualan minuman beralkohol tersebut telah jelas terdapat tempat-tempat yang diberikan izin dan dilarang untuk sembarang memperjualbelikan minuman beralkohol, namun pada kenyataannya masih terdapat beberapa pelaku usaha minuman beralkohol yang tidak mematuhi dan mengabaikan peraturan yang telah ditetapkan oleh pemerintah. 
Peneliti akan berfokus kepada Dinas Perindustrian dan Perdagangan Kota Palangka Raya sebagai instansi yang ditunjuk untuk melaksanakan Peraturan Daerah Nomor 23 tahun 2014 tentang Retribusi Izin Tempat Penjualan Minuman Beralkohol dan kepada Pemilik Toko Minuman Beralkohol, dikarenakan ingin mengetahui bagaimana pelaksanaan Peraturan Daerah tersebut selama ini, apakah sudah berjalan dengan benar atau tidak Peraturan Daerah tersebut.

\section{METODOLOGI}

Jenis penelitian ini menggunakan deskriptif kualitatif (Sugiono, 2017:15) yaitu penelitian yang mengumpulkan data berupa kata, kalimat, skema dan gambar. Penulis berusaha mengetahui gelajala-gejala yang terjadi pada objek penelitian yang berlangsung pada waktu tertentu dan kemudian menggambarkan kejadiankejadian dengan data yang di dapat dari hasil pengamatan dan penelitian di lapangan. Untuk itu penulis menggunakan teknik pengumpulan data yaitu melalui observasi, wawancara, dan dokumentasi. Dengan dasar penelitian tersebut, maka diharapkan penelitian ini mampu memberikan gambaran yang jelas, terinci dan ilmiah.

Dalam proses wawancara, penulis menggunakan 4 (empat) Indikator implementasi kebijakan Jan Merse (Sulila, 20I5: 62) yaitu Informasi, Isi Kebijakan, Dukungan Masyarakat dan Pembagian Potensi. Sumber data primer dalam penelitian ini adalah Kepala Dinas Perindustrian dan Perdagangan, Kepala Seksi Bina Usaha, Pemasaran dan Pendaftaran Dinas Perindustrian dan Perdagangan Kota Palangka Raya, Penjual Minuman Beralkohol di Kota Palangka Raya dan juga masyarakat Kota Palangka Raya. Sedangkan data sekunder dalam penelitian ini adalah dokumen resmi yaitu Peraturan Daerah Nomor 23 Tahun 2014.

\section{HASIL DAN PEMBAHASAN}

Berdasarkan hasil penelitian tentang Implementasi Peraturan Daerah Nomor 23 Tahun 2014 tentang Retribusi Izin Tempat Penjualan Minuman Beralkohol Kota Palangka Raya maka dapat dijelaskan sebagai berikut:

I. Informasi

Salah satu faktor yang mempengaruhi implementasi suatu kebijakan/program adalah informasi. Informasi merupakan data fakta, suatu nilai yang bermanfaat. Informasi tergantung dari tiga hal yaitu informasi harus akurat, yang berarti informasi harus bebas dari kesalahan-kesalahan dan tidak bias atau menyesatkan. Akurat juga berarti informasi harus jelas mencerminkan maksudnya. Tepat pada waktunya berarti informasi yang datang kepada penerima tidak boleh terlambat. Relevan berarti, informasi tersebut mempunyai manfaat untuk pemakainya. Informasi kebijakan publik perlu disampaikan agar para pelaku kebijakan dapat mengetahui, memahami apa yang menjadi isi, tujuan, arah, kelompok sasaran (target groups) kebijakan agar para pelaku kebijakan dapat mempersiapkan dengan benar apa yang harus dipersiapkan dan lakukan untuk melaksanakan kebijakan public agar apa yang menjadi tujuan dan sasaran kebijakan dapat dicapai sesuai yang diharapkan.

Dari wawancara yang telah dilakukan peneliti dengan berbagai narasumber yang relevan maka didapatkan hasil penelitian bahwa pemberian informasi mengenai Peraturan Daerah Nomor 23 Tahun 2014 tentang Retribusi Izin Tempat Penjualan Minuman Beralkohol Kota Palangka Raya yang disampaikan oleh Pegawai Dinas Perindustrian dan Perdagangan Kota Palangka Raya kepada pemilik Toko Minuman Beralkohol sudah dilaksanakan dengan mengundang para penjual Minuman Beralkohol untuk mengikuti kegiatan sosialisasi yang diselenggarakan oleh Dinas 
Perindustrian dan Perdagangan dibuktikan dengan para Penjual Minuman Beralkohol yang sudah mengerti dan memahami isi Peraturan Daerah Nomor 23 Tahun 2014.

Selanjutnya, hasil penelitian menunjukkan tentang kendala Dinas Perindustrian dan Perdagangan dalam memberikan informasi kepada Penjual Minuman Beralkohol bahwa kendala untuk pemberian informasinya adalah ada beberapa penjual yang terlambat dalam mengikuti kegiatan sosialisasi sehingga penyampaian informasinya tidak bisa maksimal. Untuk kendala Penjual Minuman Beralkohol dalam menerima informasi menyatakan bahwa selama mengikuti kegiatan sosialisasi tersebut tidak ada kendalanya sama sekali karena Dinas Perindustrian dan Perdagangan Kota Palangka Raya sudah dengan baik dalam menyampaikan isi Peraturan Daerah tersebut.

2. Isi Kebijakan

Salah satu faktor yang turut mempengaruhi implementasi kebijakan adalah isi kebijakan yakni menyangkut tujuan dan sasaran yang merupakan standar yang digunakan dalam kebijakan. Kebijakan dapat gagal karena ketidakjelasan isi kebijakan merupakan potensi lahirnya distorsi dalam implementasi kebijakan, masih samarnya isi atau tujuan kebijakan atau kekurangan yang sangat berarti atau adanya kekurangan yang menyangkut sumberdaya.

Berdasarkan hasil penelitian bahwa pelaksanaan isi kebijakan mengenai Peraturan Daerah Nomor 23 Tahun 2014 tentang Retribusi Izin Tempat Penjualan Minuman Beralkohol Kota Palangka Raya yang dilaksanakan oleh pegawai Dinas Perindustrian dan Perdagangan Kota Palangka Raya untuk dipatuhi para pemilik Toko Minuman Beralkohol sudah dijalankan dan diterapkan secara maksimal dan baik oleh Dinas Perindustrian dan Perdagangan Kota Palangka Raya kepada para pemilik Toko Minuman Beralkohol Kota Palangka Raya.

Hal tersebut dibuktikan dengan para penjual Minuman Beralkohol sudah memahami isi kebijakan dan mengetahui sanksi yang akan diberikan Dinas Perindustrian dan Perdagangan jika melakukan pelanggaran dan aktifnya para pemilik Toko Minuman Beralkohol dalam pembayaran Tarif Retribusi. Akan tetapi para penjual Minuman Beralkohol masih kesulitan dalam mengikuti isi kebijakan Peraturan Daerah Nomor 23 Tahun 2014 pasal 28 (I) yaitu dalam penjualan Minuman Beralkohol kepada pelajar atau berusia dibawah 17 tahun yang dibuktikan dengan menunjukan kartu identitas diri, para penjual masih sulit dalam meminta kartu identitas karena beralasan akan menghambat usahanya saja. Penjual merasa hanya dengan melihat wajahnya saja mereka sudah mengetahui usia pembeli minuman beralkohol tersebut. Hal ini justru akan melanggar Peraturan Daerah jika Penjual Minuman Beralkohol tidak mengikuti aturan yaitu meminta kartu identitas jika ada remaja yang membeli Minuman Beralkohol tersebut karena penjual bisa dikelabuhi hanya dengan melihat dari wajahnya dan tidak mengetahui usianya yang sebenarnya bisa saja wajah remaja tersebut lebih tua dari usianya yang sebenarnya.

3. Dukungan Masyarakat

Salah satu faktor yang mempengaruhi keberhasilan implementasi kebijakan adalah dukungan masyarakat. Lanjutnya, bahwa setiap implementasi kebijakan tetap membutuhkan dukungan masyarakat atau partisipasi masyarakat. Apabila pada pelaksanaanya tidak cukup dukungan untuk kebijakan tersebut, maka implementasi kebijakan akan sulit untuk dilaksanakan. Dukungan yang dimaksud berkaitan kuat dengan partisipasi masyarakat. Jadi program akan berlangsung secara berkelanjutan jika didukung oleh tingkat 
pelaksanaan, pemantauan, pelaporan maupun evaluasi setiap program yang dikerjakan.

Dukungan yang dimaksudkan dalam hal ini berupa dukungan fisik maupun non-fisik. Apabila pada pelaksanaanya tidak cukup dukugan untuk kebijakan tersebut, maka implementasi kebijakan akan sulit dilaksanakan. Dukungan berkaitan kuat dengan partisipasi masyarakat. Jadi program akan berlangsung secara berkelanjutan jika didukung oleh tingkat partisipasi masyarakat yang tinggi, dalam berbagai tahapan yang ada, baik tahap perencanaan, pelaksanaan, pemantauan, pelaporan maupun evaluasi yang dikerjakan.

Berdasarkan hasil pengamatan dan wawancara kepada Masyarakat Kota Palangka Raya terkait Dukungan Masyarakat terhadap adanya Peraturan Daerah Nomor 23 Tahun 2014 tentang Retribusi Izin Tempat Penjualan Minuman Beralkohol Kota Palangka Raya, maka penulis merasa ada beberapa hal yang harus diperhatikan terkait dalam Dukungan Masyarakat tersebut.

Dalam hal ini masyarakat Kota Palangka Raya sangat mendukung dengan adanya Peraturan Daerah tersebut karena dengan adanya Peraturan Daerah tersebut Penjual Minuman Beralkohol akan lebih memperhatikan hal-hal yang ditetapkan di dalam Peraturan Daerah sehingga penjual tidak akan melakukan pelanggaran. Dukungan masyarakat Kota Palangka Raya lainnya adalah dengan ikut andil dalam pengawasan terhadap Toko Minuman Beralkohol yang berada disekitarnya dan melaporkan kepada instansi terkait apabila ada pelanggaran terhadap Toko Minuman Beralkohol tersebut.

4. Pembagian Potensi

Pembagian Potensi merupakan pembagian wewenang dan tanggung jawab. Kewenangan adalah kekuasaan tertentu yang dipunyai dan secara formal diakui pihak-pihak lain untuk menggunakan peralatan yang tersedia dalam melaksanakan kebijakan. Kewenangan berkaitan dengan posisi yang bersangkutan dan peraturan perundangundangan yang mengaturnya.

Berikutnya, berdasarkan hasil wawancara tentang koordinasi Dinas Perindustrian dengan Instansi-instansi yang terlibat dalam kebijakan Peraturan Daerah Nomor 23 Tahun 2014 bahwa Dinas Perindustrian dan Perdagangan sudah berkoordinasi dengan Dinas Penanaman Modal dan Pelayanan Terpadu Satu Pintu Kota Palangka Raya, Satuan Polisi Pamong Praja Kota Palangka Raya Aparat Kepolisian Kota Palangka Raya dan Bea Cukai Kota Palangka Raya dalam hal penegakan dan razia terhadap Toko-Toko Minuman Beralkohol di Kota Palangka Raya.

Dalam koordinasi Dinas Perindustrian dan Perdagangan Kota Palangka Raya dengan InstansiInstansi yang terlibat dalam kebijakan Peraturan Daerah tersebut bahwa selama melakukan koordinasi tersebut tidak ada kendalanya sama sekali karena sudah cukup jelas pembagian tugastugasnya antara Dinas Perindustrian dan Perdagangan Kota Palangka Raya dan InstansiInstansi yang terlibat tersebut sudah cukup baik dalam melaksanakan tugas-tugasnya ketika berkoordinasi.

\section{KESIMPULAN}

Berdasarkan hasil pengamatan dan pembahasan penelitian ini, maka penulis dapat menyimpulkan bahwa: Implementasi Peraturan Daerah Nomor 23 Tahun 2014 tentang Retribusi Izin Tempat Penjualan Minuman Beralkohol merupakan peraturan yang mengatur tentang Pengawasan, Pembinaan dan Penarikan Tarif Retribusi.

Dalam Pelaksanaannya Dinas Perindustrian dan Perdagangan Kota Palangka Raya telah menyampaikan 
informasi mengenai Peraturan Daerah Nomor 23 Tahun 2014 kepada Penjual Minuman Beralkohol di Kota Palangka Raya dalam bentuk kegiatan Sosialisasi. Untuk menunjang keberhasilan pelaksanaan Peraturan Daerah Nomor 23 Tahun 2014 telah dilakukan koordinasi dengan Dinas Penanaman Modal dan Pelayanan Terpadu Satu Pintu Kota Palangka Raya, Bea Cukai Kota Palangka Raya, Aparat Kepolisian Kota Palangka Raya dan Aparat Satpol PP Kota Palangka Raya. Faktor yang menghambat keberhasilan pelaksanaan Peraturan Daerah Nomor 23 Tahun 2014 antara lain yaitu: Sulitnya beberapa Penjual Minuman Beralkohol untuk hadir tepat waktu dalam menghadiri kegiatan sosialisasi sehingga penyampaian informasi tentang Peraturan Daerah Nomor 23 Tahun 2014 tidak bisa maksimal karena beberapa Penjual Minuman Beralkohol tersebut tidak mengikuti kegiatan sosialisasi tersebut dari awal dan masih sulitnya para Penjual Minuman Beralkohol dalam meminta kartu identitas kepada para pembeli remaja mereka hanya memperhatikan dari seragam sekolahnya saja jika memakai seragam mereka akan langsung menolak. Akan tetapi untuk meminta kartu identitas mereka masih kesulitan karena takut akan mempengaruhi usahanya.

Dalam hal ini peneliti menyarankan yaitu :

I. Penulis menyarankan agar kiranya Dinas Perindustrian dan Perdagangan Kota Palangka Raya untuk memberikan teguran bagi para Penjual Minuman Beralkohol yang terlambat dalam mengikuti kegiatan Sosialisasi karena dengan keterlambatan tersebut akan tidak memaksimalkan pemberian informasi dalam kegiatan sosialisasi tersebut.,

2. Penulis menyarankan agar kiranya Dinas Perindustrian dan Perdagangan Kota Palangka Raya untuk lebih mempertegas lagi dalam pemberian informasi mengenai Peraturan tentang larangan menjual minuman beralkohol kepada pelajar atau berusia dibawah 17 tahun yang dibuktikan dengan menunjukan kartu identitas diri karena hasil dari wawancara didapatkan bahwa masih ada beberapa penjual yang masih kesulitan dalam meminta identitas kepada para pembeli remaja karena beralasan akan mempengaruhi dan mempersulit usahanya.

\section{REFERENSI}

Anggara, Sahya. 2012. Ilmu Administrasi Negara. Bandung : CV Pustaka Setia

Anggito, Albi dan Setiawan, Johan. 2018. Metodologi Penelitian Kualitatif. Sukabumi : CV Jejak

Arikunto, Suharsimi. 2010. Prosedur Penelitian Suatu Pendekatan Praktik. Jakarta : PT Bina Aksara

Bungin, Burhan. 2012. Analisa Data Peneltian Kualitatif. Jakarta : Rajawali Pers

Hutahaean, Jeperson. 20I4. Konsep Sistem Informasi. Yogyakarta : CV Budi Utama

Indiahono, Dwiyanto. 2009. Kebijakan Publik. Purwokerto : Gaya Media

Indriantoro, Nur dan Supomo, Bambang. 2013. Metodologi Penelitian Bisnis Untuk Akuntansi \& Manajemen. Yogyakarta : BPFE

Pasolong, Harbani. 20II. Teori Administrasi Publik. Bandung : Alfabeta

Peraturan Daerah Kota Palangka Raya Nomor 23 Tahun 2014 Tentang Retribusi Izin Penjualan Tempat Minuman Beralkohol

Pudyatmoko, Y. Sri. 2009. Perizinan - Problem, dan Upaya Pembenahan. Jakarta : Grasindo

Sadi, Muhammad. 20 I7. Pengantar Ilmu Hukum. Jakarta : Kencana

Soebachi, Imam. 2013. Judicial Review (Perda Pajak dan Retribusi Daerah). Jakarta : Sinar Grafika

Sore, Uddin B dan Sobirin. 2017. Kebijakan Publik. Makassar : CV Sah Media

Sugiyono. 2017. Metode Penelitian Kuantitatif, Kualitatif, R\&D. Bandung: Alfabeta 
Sudarto. 2018. Masailul Fiqhiyah Al-Haditsah. Yogyakarta : CV Budi Utama

Sulila, Ismet. 2015. Implementasi Dimensi Pelayanan Publik Dalam Konteks Otonomi Daerah. Yogyakarta : CV Budi Utama

Sutedi, Adrian. 2010. Hukum Perizinan Dalam Sektor Pelayanan Publik. Jakarta : Sinar Grafika

Undang Undang Nomor 28 Tahun 2009 tentang Pajak Daerah dan Retribusi Daerah

Zuraida, Ida. 20I4. Teknik Penyusunan Peraturan Daerah tentang Pajak Daerah dan Retribusi Daerah. Jakarta : Sinar Grafika 